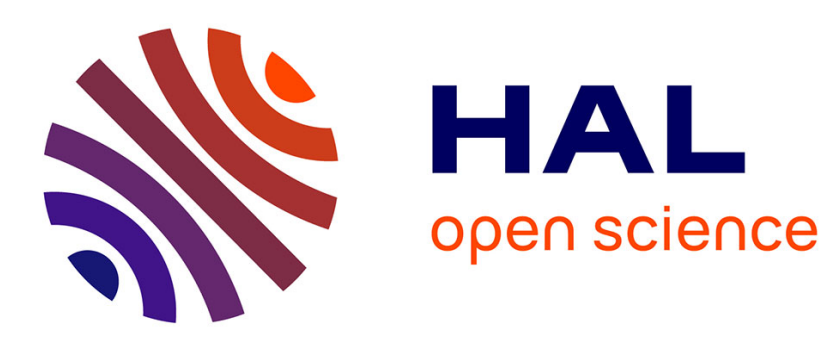

\title{
Valence State of Cerium Incorporated in Aluminium-Free Layered Silicates
}

\author{
M. Dubiel, S. Brunsch, W. Schwieger, U. Brenn
}

\section{To cite this version:}

M. Dubiel, S. Brunsch, W. Schwieger, U. Brenn. Valence State of Cerium Incorporated in AluminiumFree Layered Silicates. Journal de Physique IV Proceedings, 1997, 7 (C2), pp.C2-813-C2-814. 10.1051/jp4:1997243 . jpa-00255322

\section{HAL Id: jpa-00255322 https://hal.science/jpa-00255322}

Submitted on 1 Jan 1997

HAL is a multi-disciplinary open access archive for the deposit and dissemination of scientific research documents, whether they are published or not. The documents may come from teaching and research institutions in France or abroad, or from public or private research centers.
L'archive ouverte pluridisciplinaire HAL, est destinée au dépôt et à la diffusion de documents scientifiques de niveau recherche, publiés ou non, émanant des établissements d'enseignement et de recherche français ou étrangers, des laboratoires publics ou privés. 


\title{
Valence State of Cerium Incorporated in Aluminium-Free Layered Silicates
}

\author{
M. Dubiel, S. Brunsch, W. Schwieger* and U. Brenn* \\ Department of Physics, Friedemann-Bachplatz 6, 06108 Halle, Germany \\ * Institute of Technical Chemistry, Schlossberg 2, 06108 Halle, Germany
}

\begin{abstract}
Due to their catalytic, adsorptive and exchange properties aluminium-free layered silicate hydrates are interesting supplements to the well-known crystalline porous zeolites and alumophosphates. To create active sites Cerium ions were introduced into the interlayer space of metal silicate hydrates by an ion exchange process. $\mathrm{A} C \mathrm{Ce} / \mathrm{Na}$ ion exchange was carried out with a $0.1 \mathrm{~N} \mathrm{Ce}\left(\mathrm{NO}_{3}\right)_{3}$-solution at room temperature. Two types of air dried Ce-containing layered silicates, ilerite and magadiite, were analysed by XANES and EXAFS spectroscopy at the Ce $\mathrm{LII}^{-} \mathrm{edge}$. Both valence states $\mathrm{Ce}^{3+}$ and $\mathrm{Ce}^{4+}$ have been detected but $\mathrm{Ce}^{3+}$ dominated at all. The ratio of $\mathrm{Ce}^{4+} / \mathrm{Ce}^{3+}$ at ilerite was larger than that for magadiite. This result leads to the conclusion, that the local order must be higher around cerium in the ilerite.
\end{abstract}

\section{Introduction}

Layered substances, especially clay-like materials, can be used as basic materials for the formation of the so-called "pillared clays". In general, the properties of pillared materials and the pillaring process itself depend strongly on the properties of the layers, especially the layer charge density and its distribution, which are attached mainly to the structure of the bulk layer. Among layered materials the Al-free layered silicates, e.g. ilerite and magadiite, gained the most interest in the last years, because of their adsorptive behaviour [1], their capabilities for ion exchange and their use as a catalyst of chemical reactions [2,3]. A very important advantage of these silicates is their higher acid resistance compared with the instability of clay minerals in acidic surrounding [4].

Beside that these silicates possess crystallographic defined groups carrying the charges at the interface between silicate layer and interlayer [5]. On such sites the intercalated pillars can couple. However, the high charge density of the aluminium-free silicate layers limits their swelling behaviour, and therefore the realisation of the classical pillaring method with $\mathrm{Al}_{13^{-}}$ polyoxycations being impossible. Thus, to prepare three-dimensional networks with a permanent pore system the silicate layers of the metal-silicate hydrates (M-SH) must be opened by an already achieved modification method, valid only for these silicates [6].

For that the ion exchange becomes very high important in the course of our studies on the formation of inorganic pillars between the layers and also because of the formation of an catalytic activity caused by the insertion of cerium in the usual catalytical inert $\mathrm{M}-\mathrm{SH}$.

This article is concerned with structural investigations of cerium incorporations in dependence on conditions during the ion exchange and also on cerium loading in order to adjust calculated co-ordination spheres of the cerium in the interlayer. These studies were carried out on the layered silicates "ilerite" and "magadite", two of a group of the five well-known aluminiumfree metal silicate hydrates.

\section{Experimentals}

The layered silicates had been synthesised hydrothermally using procedures as shown in [7], which are characteristic for the crystallisation of M-SH. The crystallisation was carried out in the temperature range of $323-348 \mathrm{~K}$. The composition of the mixture needed for this reaction (given in mole ratio of oxides) was the following:

$$
4 \mathrm{SiO}_{2} / 1 \mathrm{Na}_{2} \mathrm{O} / 30 \mathrm{H}_{2} \mathrm{O} \text { for ilerite } \quad 9 \mathrm{SiO}_{2} / 1 \mathrm{Na}_{2} \mathrm{O} / 75 \mathrm{H}_{2} \mathrm{O} \text { for magadiite }
$$

Colloidal silica (Chemiewerk Köstritz), sodium hydroxide $\left(97 \% \mathrm{H}_{2} \mathrm{O}\right)$ and water were used as raw materials. The assynthesised products were filtered, washed with deionised water and dried at $80^{\circ} \mathrm{C}$ in air.

The ion exchange was performed in a stirred batch method at room temperature. As an ion-exchange mixture $1 \mathrm{~g}$ of an airdried fine grained silicate was added to $100 \mathrm{ml}$ of a $0.1 \mathrm{~N} \mathrm{Ce}\left(\mathrm{NO}_{3}\right)_{3} * 6 \mathrm{H}_{2} \mathrm{O}$ solution, to keep the ratio solid/liquid matter always constant at $1 / 100$. The crystalline structure of the products was described by $\mathrm{X}$-ray diffraction.

To investigate the coordination state of cerium in ilerite and magadiite samples we used Ce(II)chlorid-7-hydrate and $\left(\mathrm{NH}_{4}\right) \mathrm{Ce}\left(\mathrm{SO}_{4}\right)_{4} \mathrm{H}_{2} \mathrm{O}$ as $\mathrm{Ce}^{3+}$ and $\mathrm{Ce}^{4+}$ reference, respectively. The samples were powdered, mixed with boron nitride or pressed with polyethylene to tablets. 
The XAFS spectra were performed at HASYLAB in Hamburg using the EXAFS II beamline and a Si(111) monochromator on the cerium $\mathrm{L}_{\mathrm{II}}$-edge $(\mathrm{E}=5.7234 \mathrm{keV})$ with transmission mode. All spectra were taken at room temperature till an energy about $400 \mathrm{eV}$ above the absorption edge. The absorption edge was defined as the first inflection point.

\section{Results and Discussion}

The XANES spectra of the $\mathrm{Ce}^{4+}$ reference are characterised by a remarkable splitting of the white line caused by two different configurations in the initial state [8]. The first peak corresponds to the initial configuration $4 f^{1} \underline{L}$ and the second to $4 f^{0}$, but both peaks can be described by a $2 \mathrm{p}-5 \mathrm{~d}$ transition. In the case of the $\mathrm{Ce}^{3+}$ reference it exists only one peak that corresponds to the $2 p\left(4 \mathbf{f}^{1}\right)-5 d$ transition.

A XANES fit of energy calibrated and normalised XANES spectra of Ce-magadiite and Ce-ilerite was performed including two arctangent and three Lorentzian functions [9] (Fig.1). Both samples show a mixture of $\mathrm{Ce}^{3+}$ and $\mathrm{Ce}^{4+}$ states. The ratio of $\mathrm{Ce}^{4+} / \mathrm{Ce}^{3+}$ of $\mathrm{Ce}$-ilerite was larger than that of Ce-magadiite, i.e. in the case of ilerite 0,25 and of magadiite 0,10 , respectively. This effect can be interpreted by an increased local order around cerium in $\mathrm{Ce}$-ilerite, caused by well defined positions of cerium ions within the silicate layers.

An anomalous structure due to double electron transition $2 \mathrm{p} 4 \mathrm{~d} \rightarrow 5 \mathrm{~d}^{2}$ was eliminated from the spectra in order to avoid an effect to our analysis. The radial distribution function obtained from EXAFS analysis of Ce-ilerite shows two coordination spheres (Fig.2). The first peak corresponds to a Ce-O correlation with a distance of $2.58 \AA$ and a co-ordination number of 2 . The second peak contains overlapping contributions of one oxygen at a distance of $3.22 \AA$ and of one cerium at a distance of $3.45 \AA$. This results could be described by a bridging effect between the cerium atom and the tetrahedrons of the silicate layers. Considering the earlier proposed model for the layered silicates [7] always two tetrahedrons of the building unit (single- 4 chains) carrying the charges balanced by a sodium cation and a proton. These two cations are exchangeable. Thus, a coordination number of two would be expected if cerium is attached to one layer surface only. A decrease of the basal spacing leads to an increase of the coordination state of cerium. During this process Si-OH groups of the opposite layer will reach distances to the cerium close enough to coordinate.

The studies show the possibility to investigate the incorporation of cerium in layered silicates. Further systematic investigations are nessesary to explain the macroscopic properties of such materials.

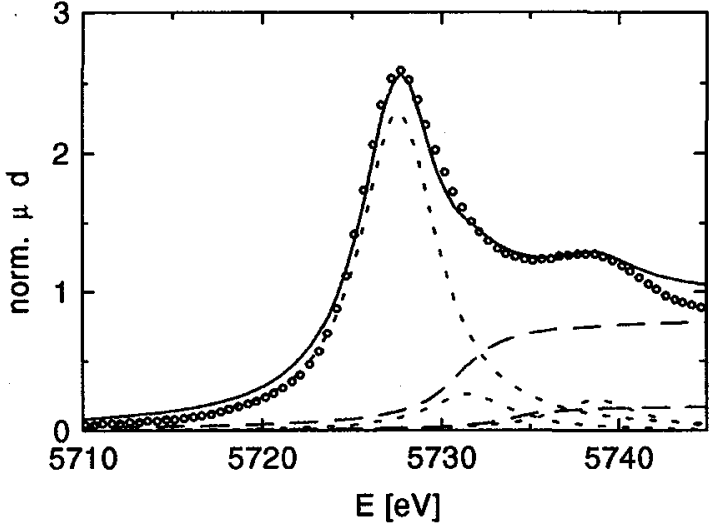

Figure 1: XANES fit of ilerite (symbols: measured data; solid line: fitted data)

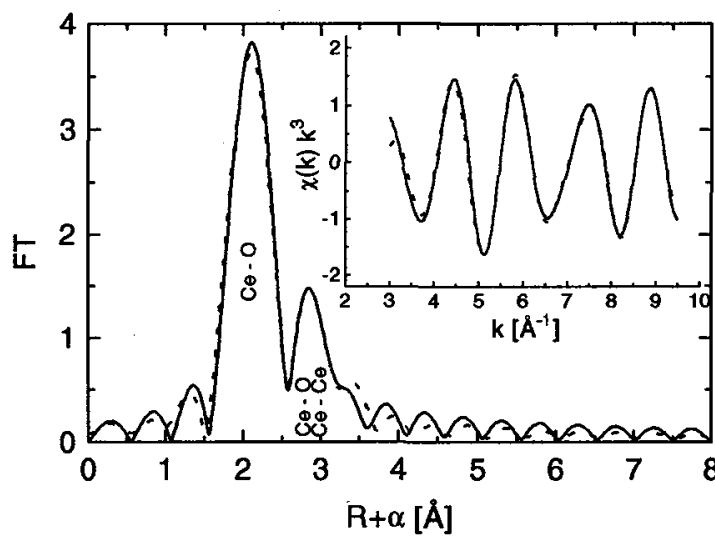

Figure 2: Fourier transforms of EXAFS oscillations at the cerium LiI-Edge for ilerite (solid line: measured data; dash line: fitted data)

\section{References}

[1] J.Döring, K.Beneke, G.Lagaly; Colloid Polym. Sci. 270 (1992) 609

[2] DE-OS 3123000

[3] W.Schwieger, K.-H.Bergk, W.Reschetilowski, K.-P.Wendlandt; Z.Chem. 28 (1988) 107

[4] K.-H.Bergk, W.Schwieger, M.Porsch; Chem. Technik 39. Jg. Heft 11 (1987) 459

[5] W.Schwieger, K.Pohl, U.Brenn, C.Fyfe, H.Grondey, G.Fu, G.Kokotailo; Stud. Surf. Sci. Catal. 24 (1995) 47

[6] W.Schwieger, K.Pohl, U.Brenn, H.G.Karge; Stud. Surf. Sci. Catal. 84 (1994) 275

[7] W.Schwieger, D.Heidemann, K.-H.Bergk; Rev. De Chim. Min. 22 (1985) 639

[8] A.Bianconi, A. Kotani, K.Okada, R.Giorgi, A. Gargano, A. Marcelli and T.Miyahara, Phys. Rev. B 38 (1988) 3433.

[9] K. Lochte, M. Fröba, T. Ressler, W. Metz, Physica B 208\&209 (1995) 281-282.

[10] J.A. Solera, J. Garcia, M.G. Proietti, M.C. Sanchez, Physica B 208\&209 (1995) 71-72 